Pelatihan Motivasi Berprestasi dan Orientasi Masa Depan Remaja Jatinangor (Yanti Rubiyanti, Langgersari Elsari Novianti dan Dika Supyandi)

\title{
PELATIHAN MOTIVASI BERPRESTASI DAN ORIENTASI MASA DEPAN REMAJA JATINANGOR
}

\author{
${ }^{1}$ Yanti Rubiyanti, ${ }^{1}$ Langgersari Elsari Novianti dan ${ }^{2}$ Dika Supyandi \\ ${ }^{1}$ Fakultas Psikologi Universitas Padjadjaran \\ ${ }^{2}$ Fakultas Pertanian Universitas Padjadjaran \\ Email:yanti.rubiyanti@gmail.com
}

\begin{abstract}
ABSTRAK. Penelitian ini merupakan penelitian terapan yang bertujuan untuk melihat peran pelatihan motivasi berprestasi dalam memperjelas orientasi masa depan remaja di Jatinangor. Orientasi masa depan adalah gambaran individu tentang dirinya dalam konteks masa depan, yang akan membantu individu mengarahkan dirinya untuk mencapai sejumlah perubahan yang sistematis, guna meraih apa yang diinginkannya (Nurmi, 1989). Pendekatan dalam penelitian ini adalah pendekatan eksperimental Posttest Design untuk melihat peran pelatihan. Alat ukur yang digunakan adalah catatan observasi, kuesioner evaluasi pelatihan, dan kuesioner orientasi masa depan. Hasil penelitian menunjukkan bahwa orientasi masa depan (OMD) remaja di Jatinangor tergolong tinggi, artinya remaja di Jatinangor sudah memiliki OMD yang jelas. Kontribusi yang paling besar dalam OMD remaja ini adalah aspek motivasi. Aspek perencanaan dan evaluasi masih tergolong sedang. Ini menunjukkan bahwa remaja masih membutuhkan arahan untuk mendapatkan strategi dan cara-cara di dalam merencanakan masa depannya. Pelatihan motivasi berprestasi yang dilakukan membantu remaja merencanakan dan menetapkan tujuan dan membuat strategi untuk merealisasikan perencanaan. Setelah pelatihan, remaja mengungkapkan bahwa dirinya lebih termotivasi untuk melanjutkan pendidikan ke jenjang yang lebih tinggi, mengetahui strategi untuk meneruskan pendidikan, mendapatkan pengetahuan mengenai jurusan yang diminati, dan pekerjaan yang dapat ditekuni di masa yang akan datang.
\end{abstract}

Kata Kunci : orientasi masa depan, remaja, training

\section{ACHIEVEMENT MOTIVATION TRAINING AND FUTURE ORIENTATION ADOLESCENT OF JATINANGORS ADOLESCENCE}

ABSTRACT. The research is an applied research which is propose to intended the role of achievement motivation training in clarifying the future orientation of adolescence in Jatinangor. Future orientation is individual schema about self in the future context, will to help the individual toward to reach amount changes sistematically, to intended what they need (Nurmi, 1989). The approach in this research is experimental approach with Posttest Design to look for the role a training. The instrument is an observation notes, training evaluation questionnaire and future orientation questionnaire. The result of the research show of future 
orientation of adolescence in Jatinangor is high category. It means, the adolescence in Jatinangor has been clarified future orientation. The high contribution is motivasional aspect. For planning and evaluation aspect is average category. This suggest that adolescents still need direction to get the strategy and the ways in planning their future. The achivement motivation training helping the adolescence to plan, goal setting, and making strategy to realize their plan. After training, adolescence publish that they have been motivated to futher their study, to get strategy for pursuit study, to get information about the programme in the university and future career.

Keywords: future orientation, adolescence, training

\section{PENDAHULUAN}

Masa remaja merupakan periode terjadinya perubahan-perubahan yang berhubungan dengan perkembangan psikoseksual, perubahan dalam hubungan dengan orangtua dan cita-cita. Pembentukan cita-cita merupakan proses pembentukan orientasi masa depan. Terkait dengan orientasi masa depan, remaja dituntut untuk mempersiapkan kemampuan diri dan menetapkan rencana individu di masa yang akan datang guna mengarahkan tingkah lakunya untuk mencapai apa yang diinginkan atau dicita-citakannya. Gambaran individu ini disebut orientasi masa depan, yang dalam pemahaman remaja dikenal dengan istilah cita-cita. Mengacu pada konsep orientasi masa depan dari Nurmi (1989), terdapat tiga bidang orientasi masa depan, yaitu bidang pendidikan, karir dan pekerjaan serta kehidupan perkawinan dan keluarga.

Hasil wawancara dengan beberapa remaja khususnya siswa SMA di Jatinangor menunjukkan bahwa remaja di Jatinangor belum memiliki gambaran yang jelas mengenai rencana ke depan setelah lulus SMA. Data lainnya menunjukkan bahwa beberapa remaja sudah bisa menyebutkan pilihan pendidikan lanjutan dan jenis atau bidang pendidikan, namun mereka belum mengetahui pengetahuan apa dan informasi apa yang dibutuhkan untuk bisa melanjutkan pendidikan yang sudah mereka tetapkan. Berdasarkan konsep orientasi masa depan dari Nurmi (1989), remaja dalam hal ini belum memiliki pengetahuan kontekstual yang dapat membantu motivasi remaja di dalam perencanaan pendidikan di masa depan. Pemberian motivasi bisa mengantarkan remaja pada dorongan untuk mencapai suatu tujuan. Tujuan remaja siswa SMA secara umum di bidang pendidikan adalah melanjutkan sekolah ke perguruan tinggi. Melanjutkan sekolah ke perguruan tinggi merupakan salah satu rancangan dimana remaja memulai menyusun orientasi masa depannya.

Berdasarkan hasil analisis situasi di SMAN Jatinangor diperoleh gambaran bahwa siswa-siswa memiliki keinginan untuk bisa melanjutkan sekolah ke PT. Akan tetapi, keinginan tersebut belum didukung dengan informasi dan motivasi yang cukup untuk memantapkan dorongan para siswa untuk melanjutkan ke perguruan tinggi. 


\begin{abstract}
Pelatihan motivasi berprestasi memberikan pembelajaran dan pengalaman yang berkaitan dengan bagaimana seseorang diajak membayangkan, merencanakan, dan menyusun strategi untuk mencapai tujuan. Dalam kaitannya dengan orientasi masa depan, mencapai tujuan diawali dengan motivasi. Pembelajaran dan pengetahuan mengenai motivasi berprestasi dan latihan rencana tindakan yang diberikan kepada remaja akan memperjelas orientasi masa depan remaja. Oleh karenanya dalam penelitian ini ingin dilihat apakah pemberian informasi melalui program pelatihan motivasi berprestasi memiliki peranan dalam memperjelas orientasi masa depan remaja siswa kelas XII di Jatinangor.

Peneliti telah melakukan pelatihan motivasi berprestasi pada bulan Januari 2011 pada remaja-remaja siswa SMAN 1 Jatinangor. Pelatihan tersebut diikuti oleh 118 siswa kelas XII IPA SMAN 1 Jatinangor. Penelitian ini merupakan lanjutan dari kegiatan pelatihan tersebut, dan ditujukan untuk mengkaji peranan pelatihan motivasi berprestasi yang telah diselenggarakan terhadap kejelasan orientasi masa depan bidang pendidikan pada peserta pelatihan. Berdasarkan hasil analisis di atas, maka rumusan masalah dalam penelitian ini adalah, "Pelatihan motivasi berprestasi memiliki peran dalam memperjelas orientasi masa depan bidang pendidikan pada remaja di Jatinangor".
\end{abstract}

Orientasi masa depan adalah gambaran individu tentang dirinya dalam konteks masa depan, yang akan membantu individu mengarahkan dirinya untuk mencapai sejumlah perubahan yang sistematis guna meraih apa yang diinginkannya. Menurut Jari-Erik Nurmi (1989), orientasi masa depan ini terkait dengan harapan, tujuan, standar, ketertiban, rencana, dan strategi yang akan dihadapi di masa depan.

Orientasi masa depan dapat digambarkan melalui tiga tahap proses yang berinteraksi dengan schemata individu mengenai masa depan dan perkembangan diri yang diantisipasinya. Schemata yang disusun individu dalam mengantisipasi masa depan akan memberikan gambaran mengenai diri dan lingkungan dalam konteks masa depan. Schemata tersebut berisi perkembangan sepanjang life-span yang diantisipasi, pengetahuan sesuai konteks, keterampilan, konsep diri dan attributional style. Individu mencoba mengantisipasi kejadian di masa depan dan memberi makna pribadinya dengan schemata ini. Sebagai konsekuensinya, minat dan motivasi menjadi bagian dari keadaan masa depan yang direncanakan itu.

Mengacu pada schemata yang ada, individu membentuk harapan-harapan baru yang ingin diwujudkan di kehidupan mendatang. Schemata individu akan berinteraksi dengan tiga tahap proses orientasi masa depan: motivasi, perencanaan, dan evaluasi. Motivasi mengacu pada minat individu di masa depan. Aktivitas perencanaan mengacu pada tindakan individu untuk merealisasikan penilaian terhadap sejumlah minat yang diharapkan dapat terwujud (Nurmi, 1989).

Perkembangan motivasi merupakan suatu tahapan proses. Pada mulanya individu menunjukkan minat terhadap satu atau beberapa hal yang diinginkan di masa datang. Minat ini mendorong individu melakukan eksplorasi atau penjajakan sebelum akhirnya menetapkan tujuan masa depan. 
Perkembangan motivasi secara garis besar digambarkan dalam skema berikut:

$$
\text { Interest } \longrightarrow \text { exploration } \longrightarrow \text { goal-setting } \longrightarrow \text { commitment }
$$

kondisi motivasi seseorang dapat dilihat dari temporal extension-nya, yaitu sejauh mana individu berpikir tentang masa depannya. Hal ini berkaitan dengan tujuan yang dimiliki individu yang diharapkan terwujud pada usia tertentu.

Perencanaan. Ini adalah proses kedua, perencanaan untuk merealisasikan tujuannya. Perencanaan yang dimaksud di sini adalah suatu proses pembentukan sub-sub tujuan, mengkonstruksi perencanaan dan merealisasikan rencana tersebut (Nurmi, 1989). Hal ini dapat digambarkan melalui tiga tahapan sebagai berikut:

1) Individu mempunyai konsepsi yang merupakan suatu gambaran dari tujuan dan keadaan di masa depan. Gambaran ini didasarkan pada pengetahuan individu tentang keadaan masa depan.

2) Selanjutnya, individu membuat rencana, proyek atau strategi untuk mencapai tujuan yang telah dipilihnya. Penyusunan rencana ini tidak jauh berbeda dengan proses pemecahan masalah: individu harus menemukan berbagai cara untuk mencapai tujuan, kemudian memilih cara yang paling efisien.

3) Fase ketiga dari aktivitas perencanaan adalah menjalankan rencana serta strategi yang disusun. Pelaksanaan rencana dan strategi dikontrol dengan membandingkan antara tujuan yang ingin dicapai dengan konteks aktual atau keadaan dalam situasi nyata. Dengan kata lain, setiap tahap yang dilaksanakan individu untuk pencapaian tujuan harus dicocokkan kembali dengan tujuan awal yang telah disusun agar tujuan teraih secara sistematis.

Kondisi perencanaan individu dapat dilihat dari tiga variabel yang tercakup di dalamnya, yaitu knowledge, plans, dan realization. Individu membutuhkan pengetahuan yang berhubungan dengan tujuan dalam membentuk sub-sub tujuan untuk merealisasikan tujuan akhirnya. Jumlah pengetahuan yang ada akan mempengaruhi perencanaan yang dibuat. Plans berkaitan dengan kompleksitas dari rencana atau strategi yang dibuat individu. Sedangkan realization berkaitan dengan apa yang telah dilakukan untuk merealisasikan tujuan yang diinginkan. Diharapkan dengan bertambahnya usia maka kemampuan perencanaan (termasuk ketiga variabelnya) menjadi lebih baik, sebab dengan bertambahnya usia individu menjadi lebih memikirkan masa depannya.

Evaluasi. Pada proses evaluasi, individu akan mengevaluasi mengenai kemungkinan realisasi tujuan dan rencana yang telah disusun. Markus dan Wurf (dalam Nurmi, 1989) menggambarkan proses evaluasi sebagai serangkaian proses meliputi pemonitoran tingkah laku dan membuat keputusan mengenai bagaimana tingkah laku sebaiknya dimunculkan. Jadi, proses evaluasi merupakan penilaian kemungkinan mewujudkan tujuan dan rencana sebelum tujuan dan rencana tersebut terwujud. 
Dalam proses evaluasi juga melibatkan atribusi kausal (causal attribution) dan perasaan (affects) terhadap kejadian-kejadian di masa depan, terutama ketika melakukan evaluasi terhadap kemungkinan realisasi dari tujuan dan rencana di masa depan. Menurut Weiner, kemampuan untuk mengontrol secara internal kejadian-kejadian di masa depan akan mendatangkan perasaan penuh harap dan optimis (Nurmi, 1989).

Self-concept memainkan peranan yang penting dalam proses evaluasi (Marsh et al, dalam Nurmi, 1989): individu mengevaluasi kesempatan mereka merealisasikan tujuan dan rencananya didasarkan pada gambaran kemampuan diri mereka. Sejalan dengan hal tersebut, attributional style, bagian penting dari schemata diri, juga mempengaruhi bagaimana kecenderungan individu untuk berpikir tentang kesempatan memiliki kontrol pribadi terhadap situasi-situasi masa depan yang berbeda.

Weiner $(1974,1985)^{1}$ dan Lazarus \& Folkman $(1981)^{2}$ mengungkapkan dua jenis model evaluasi, yaitu:

1. Evaluasi utama terhadap hasil: evaluasi ini hasilnya berupa kondisi yang tidak spesifik meliputi afek positif atau negatif (Weiner); menurut Lazarus \& Folkman hasil evaluasi ini menghasilkan pengalaman berupa perasaan tertantang atau menakutkan.

2. Evaluasi kedua: menurut Weiner dilakukan terhadap atribusi penyebab yang diikuti oleh emosi-emosi spesifik, seperti pengharapan, kecewa, optimis atau pesimis; sedangkan bagi Lazarus \& Folkman evaluasi ini merupakan evaluasi tindakan yang telah dilakukan untuk mewujudkan hubungan individu dengan lingkungannya, tentu saja berkaitan dengan seberapa besar kontrol individu terhadap hasil akhir.

\section{METODE}

Penelitian ini menggunakan rancangan One Group Posttest Design dimana terdapat perlakuan yang diberikan sesudah treatment (Christensen, 2004). Dalam penelitian ini dilakukan dua pengukuran yaitu: 1) Pengukuran terhadap orientasi masa depan remaja. 2) Pengukuran terhadap pelaksanaan modul pelatihan motivasi berprestasi yang ditujukan untuk memperjelas orientasi masa depan.

Pengukuran dilakukan menggunakan kuesioner evaluasi dan catatan observasi yang didasarkan pada salah satu konsep evaluasi pelatihan dari Kirkpatrick (2006) yaitu evaluasi terhadap reaksi peserta. Pengukuran ini dilakukan untuk melihat apakah rancangan modul pelatihan motivasi berprestasi berperan dalam memperjelas orientasi masa depan remaja, berdasarkan konsep orientasi masa depan dari Nurmi (1989).

\footnotetext{
1, Jari Erik Nurmi,Planning, motivation, and evaluation in orientation to the future: $A$ latent structure analysis, Scandinavian Journal of Psychology, Volume 30, Issue 1, pages 64-71. 1989
} 


\section{HASIL DAN PEMBAHASAN}

Di bawah ini akan disajikan data hasil pengukuran Orientasi Masa Depan. Adapun hasilnya adalah sebagai berikut:

Tabel 1. Gambaran Umum Orientasi Masa Depan

\begin{tabular}{lc}
\hline \multicolumn{1}{c}{ Kategori OMD } & Prosentase \\
\hline Tinggi & $39 \%$ \\
Sedang & $61 \%$ \\
Rendah & 0 \\
\hline
\end{tabular}

Berdasarkan tabel di atas diketahui bahwa 39\% remaja di Jatinangor (siswa SMAN Jatinangor) memiliki orientasi masa depan yang tergolong tinggi. Artinya bahwa sejumlah $39 \%$ remaja telah memiliki motivasi, perencanaan, dan melakukan evaluasi terhadap pencapaian tujuannya.

Di bawah ini akan disajikan data hasil pengukuran orientasi masa depan remaja yang diukur melalui alat ukur berupa kuesioner orientasi masa depan berdasarkan dimensi-dimensi pada orientasi masa depan menurut konsep teori Nurmi. Adapun hasilnya adalah sebagai berikut:

Tabel 2. Gambaran per Dimensi Orientasi Masa Depan

\begin{tabular}{lccc}
\hline \multicolumn{1}{c}{ Dimensi } & \multicolumn{3}{c}{ Kategori (dalam \%) } \\
\cline { 2 - 4 } & Tinggi & Sedang & Rendah \\
\hline Motivasi & 53 & 27 & \\
Perencanaan & 25 & 75 & 2 \\
Evaluasi & 20 & 78 & 2 \\
\hline
\end{tabular}

Berdasarkan tabel di atas diketahui bahwa 53\% remaja di Jatinangor memiliki motivasi yang tergolong tinggi di dalam perencanaan masa depan. Motivasi adalah aspek yang paling mendominasi orientasi masa depan remaja dibandingkan kedua aspek lainnya, yakni perencanaan dan evaluasi.

Orientasi masa depan remaja Jatinangor dapat dikatakan tergolong sedang ke arah tinggi artinya bahwa remaja Jatinangor sudah memiliki gambaran tentang dirinya dalam konteks masa depan, yang akan membantu individu mengarahkan dirinya untuk mencapai sejumlah perubahan yang sistematis, guna meraih apa yang diinginkannya. Hal ini akan terkait dengan bagaimana remaja di Jatinangor memiliki harapan, tujuan, standar, ketertiban, rencana dan strategi yang akan dihadapi di masa depan. Remaja di Jatinangor memiliki orientasi masa depan yang tinggi pada dimensi motivasi dan masih cenderung sedang pada dimensi perencanaan dan evaluasi. Secara keseluruhan dapat disimpulkan bahwa orientasi masa depan remaja di Jatinangor masih tergolong sedang karena hanya pada 
dimensi motivasi yang tinggi sedangkan pada dimensi perencanaan dan evaluasi tergolong sedang.

Berdasarkan data hasil pengukuran ditemukan bahwa motivasi remaja di Jatinangor tinggi. Hal ini mengindikasikan bahwa remaja Jatinangor telah berpikir tentang masa depannya yang didasari dengan kondisi temporal tensionnya atau ketergugahan sesaat. Hal ini berkaitan dengan tujuan yang dimiliki individu, yang diharapkan terealisasi pada usia tertentu. Adanya tujuan mengindikasikan bahwa remaja di Jatinangor sudah merencanakan akan melanjutkan pendidikan ke sekolah lanjutan.

Perencanaan merupakan aspek yang diperlukan untuk merealisasikan tujuannya. Pada remaja di Jatinangor, perencanaan masa depan masih tergolong sedang, hal ini menunjukkan bahwa remaja di Jatinangor masih belum memiliki cara-cara untuk merencanakan sub-sub tujuan yang ingin dicapai di masa depan. Mereka belum memiliki bagaimana cara-cara untuk mengkonstruksi perencanaan dan merealisasikan rencana di masa depan. Hal ini terjadi karena pengetahuan tentang konteks di masa depan belum remaja miliki. Mereka memiliki pengetahuan tentang masa depan namun belum dapat membayangkan perilaku yang perlu ditampilkan di masa depan. Hal ini karena kemampuan antisipasi remaja yang kurang dan pengetahuan kontekstual yang cenderung terbatas. Oleh karenanya dalam latihan imagery, remaja diarahkan untuk dapat menentukan dan merencanakan bidang atau profesi apa yang akan mereka pilih di masa depan. Pada usia remaja, individu remaja sudah mampu merencanakan masa depannya namun masih perlu diarahkan untuk menemukan berbagai cara di dalam mencapai tujuan, kemudian memilih cara yang paling efisien.

Fase berikutnya dari aktivitas perencanaan adalah menjalankan rencana serta strategi yang disusun. Pelaksanaan rencana dan strategi dikontrol dengan membandingkan antara tujuan yang ingin dicapai dengan konteks aktual atau keadaan dalam situasi nyata. Pada remaja Jatinangor, hal ini belum semuanya tampak ada, perlu adanya bimbingan dan arahan dari lingkungan (guru dan orangtua) untuk remaja bisa melaksanakan pencapaian tujuan secara sistematis.

Kegiatan pelatihan motivasi yang dilakukan peneliti memberikan beragam materi, seperti pendidikan di perguruan tinggi, peluang kerja lulusan perguruan tinggi, kiat dan strategi lulus seleksi masuk perguruan tinggi, informasi beasiswa dan kiat untuk memperoleh beasiswa, serta berbagi pengalaman antara alumni SMAN Jatinangor yang sudah diterima di Unpad dengan remaja peserta pelatihan. Berdasarkan catatan hasil observasi kegiatan pelatihan, diperoleh data mengenai reaksi peserta/remaja dalam kegiatan pelatihan motivasi. Pada diskusi kelompok kecil, fasilitator kelompok sempat menanyakan manfaat yang dirasakan remaja setelah mengikuti kegiatan pelatihan. Berikut adalah manfaat pelatihan yang diungkapkan remaja/peserta kepada fasilitator kelompok:

(1) Merasa termotivasi \& lebih yakin untuk melanjutkan pendidikan ke PT.

(2) Memperoleh wawasan tentang PT dan kehidupan perkuliahan.

(3) Lebih memahami jurusan yang ingin diambil dan minat lebih mantap. 
(4) Lebih mengetahui lapangan pekerjaan sesuai dengan bidang yang diminati.

(5) Mengetahui mengenai jalur masuk PT, strategi, dan tes masuk yang harus diikuti.

(6) Mengetahui banyaknya beasiswa yang tersedia.

Untuk mengetahui reaksi remaja/peserta terhadap kegiatan pelatihan, peserta juga diminta mengisi kuesioner mengenai manfaat pelatihan yang dirasakan. Hasil jawaban peserta relevan dengan jawaban pada sesi di kelompok kecil. Berikut adalah manfaat kegiatan pelatihan motivasi yang dirasakan remaja/peserta:

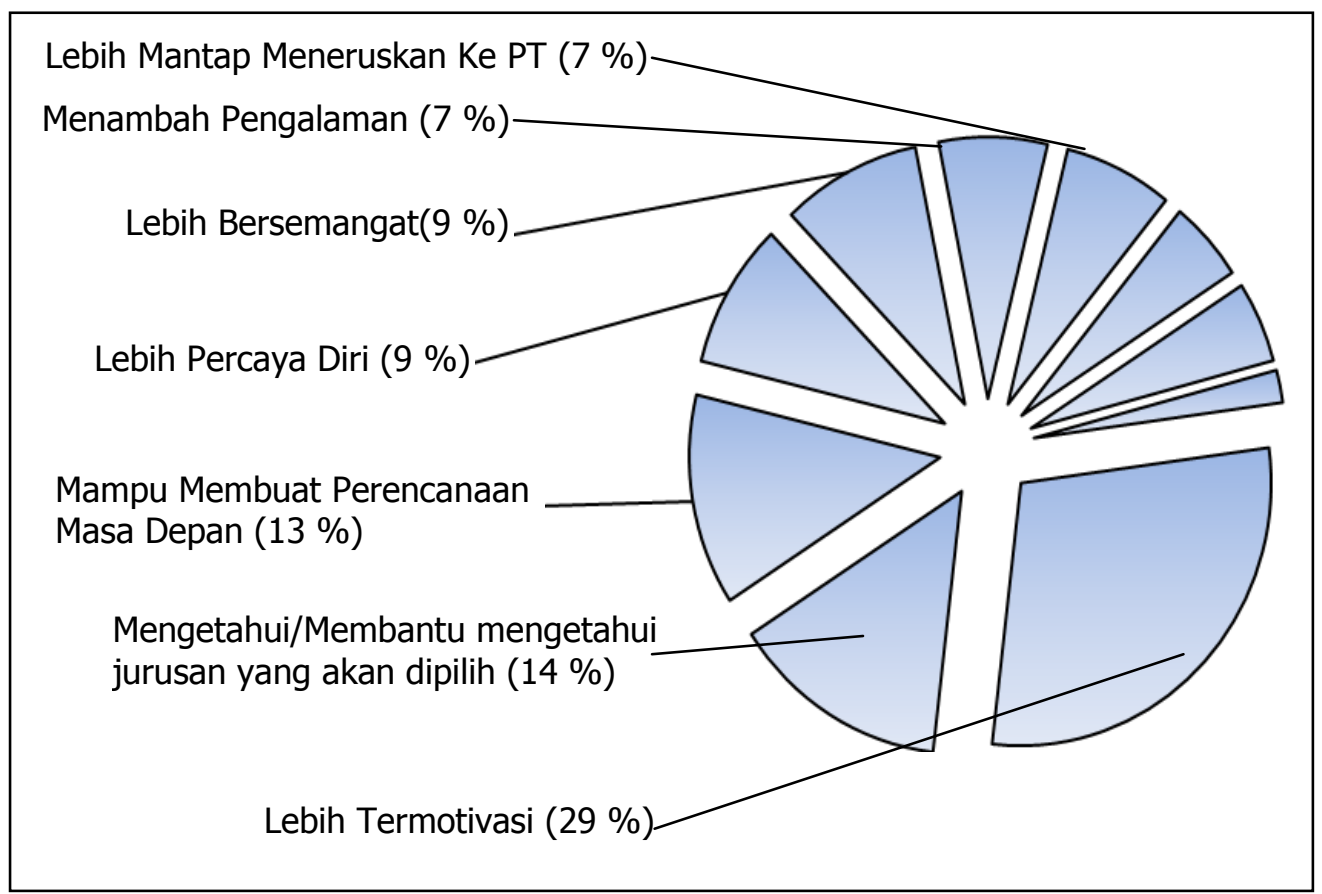

Gambar 1. Manfaat kegiatan pelatihan yang dirasakan peserta

Secara spesifik remaja/peserta juga mengungkapkan hal-hal yang diperoleh dari pelatihan motivasi yang diadakan, diantaranya $21 \%$ mendapatkan pengetahuan mengenai fakultas dan jurusan yang diminati; $17 \%$ mendapatkan wawasan tambahan; $16 \%$ mendapatkan informasi mengenai perguruan tinggi. Peserta pelatihan juga memberikan pendapat mengenai materi yang disajikan dalam kegiatan pelatihan, penilaian terhadap fasilitator, metoda yang digunakan dalam kuesioner evaluasi pelatihan. Pada setiap pernyataan yang diajukan, peserta memberikan penilaian dengan memilih angka 1 hingga 10. Semakin besar nilai 
yang diberikan peserta, mengindikasikan semakin puas peserta terhadap kegiatan pelatihan yang diikutinya.

Berikut adalah hasil pengolahan data kuesioner evaluasi yang diisi remaja/peserta:

- $\quad$ Remaja/peserta $(87,7 \%)$ memberikan nilai di atas 8 kepada materi yang diterimanya dalam kegiatan pelatihan. Hal ini mengindikasikan bahwa peserta merasa puas dengan materi yang diberikan dalam pelatihan karena dirasakan sesuai dengan kebutuhan diri mereka. Materi membayangkan masa depan (imagery), penjelasan mengenai jurusan di perguruan tinggi, beasiswa, sharing pengalaman kuliah di Unpad bersama kakak angkatan, dan diskusi di kelompok kecil telah berhasil memuaskan keingintahuan peserta akan perguruan tinggi dan memotivasi mereka untuk meneruskan pendidikannya di perguruan tinggi.

- Sekitar 65 orang (57\%) memberikan nilai 8 terhadap materi yang disajikan. Ini mengindikasikan bahwa materi yang disajikan sangat menarik perhatian mereka.

- Remaja/peserta menilai bahwa fasilitator telah memberikan materi dengan sangat jelas sehingga mudah dipahami. Sekitar 70 orang peserta $(61,4 \%)$ memberikan nilai lebih dari 8 kepada kemampuan fasilitator menjelaskan materi pelatihan.

- Sekitar 70 orang peserta $(61,4 \%)$ memberikan nilai 8 ke atas kepada kemampuan fasilitator menyiapkan materi pelatihan dengan sangat baik.

- Sekitar 70 orang peserta $(61,4 \%)$ memberikan nilai 8 ke atas untuk kesesuaian media yang dipergunakan dalam pelatihan ini, seperti media film untuk memahami mengenai kelebihan diri. Pelatihan ini lebih banyak menggunakan metoda diskusi dan sharing dengan menggunakan media/alat bantu sederhana seperti slide powerpoint, pengeras suara, dan musik, namun penggunaan media yang sederhana tersebut diapresiasi sangat baik oleh peserta pelatihan ini.

- Sekitar 90 orang peserta $(78,9 \%)$ memberikan nilai 8 ke atas pada pernyataan ini. Peserta menilai bahwa materi mengenai perguruan tinggi, kiat mengikuti seleksi masuk, pemilihan jurusan, dan beasiswa dapat diterapkan dalam perencanaan masa depan mereka. Dengan mengetahui peluang beasiswa, peserta mengetahui tindakan seperti apa yang perlu dilakukan saat ini untuk memperoleh beasiswa di masa datang, di antaranya adalah belajar dan meningkatkan nilai raport.

- Sebanyak $92 \%$ peserta memberi angka 8 dalam menilai bahwa pelatihan ini dapat membantu siswa dalam perencanaan masa depannya.

- Sebagian besar peserta (78\%) menilai bahwa metoda yang digunakan memudahkan mereka dalam memahami materi yang diberikan.

- Sebagian besar $(65,7 \%)$ peserta pelatihan ini memberikan nilai 8 ke atas terhadap metoda yang dipergunakan pada sesi pelatihan. Metoda pelatihan dinilai sesuai dengan materi yang disajikan. Kegiatan pelatihan 
ini menggunakan beragam metoda, diantaranya experiential learning pada tugas pembayangan masa depan (imagery); metoda ceramah untuk menjelaskan mengenai perguruan tinggi, dunia kerja, dan beasiswa; metoda diskusi dan berbagi pengalaman untuk mengetahui mengenai penyesuaian diri di perguruan tinggi, dan diskusi di kelompok kecil untuk mengetahui tahapan perencanaan pendidikan yang dapat dilakukan peserta sesuai dengan minat profesi yang kelak ingin ditekuninya.

\section{SIMPULAN}

Orientasi masa depan pada remaja di Jatinangor tergolong tinggi. Kontribusi yang paling besar dalam orientasi masa depan remaja Jatinangor pada aspek motivasi. Remaja di Jatinangor telah termotivasi untuk merencanakan masa depannya.

Pada aspek perencanaan dan evaluasi tergolong sedang. Hal ini menunjukkan bahwa remaja di Jatinangor sudah mampu merencanakan masa depan, namun masih membutuhkan arahan dari lingkungan (orangtua dan guru) untuk bisa memiliki cara-cara dan strategi di dalam menetapkan tujuan, dan strategi untuk merealisasi tujuan yang telah direncanakan.

Pelatihan ini telah dapat meningkatkan motivasi dan perencanaan studi remaja di Jatinangor (siswa kelas IPA SMAN 1 Jatinangor).

Manfaat yang dirasakan peserta dari pelatihan ini adalah: merasa termotivasi \& merasa lebih yakin untuk melanjutkan pendidikan ke PT; memperoleh wawasan tentang PT dan kehidupan perkuliahan; lebih memahami jurusan yang ingin diambil dan minat menjadi lebih mantap; lebih mengetahui lapangan pekerjaan sesuai dengan bidang yang diminati; menjadi tahu mengenai jalur masuk PT, strategi, dan tes masuk yang harus diikuti, dan menjadi tahu mengenai beasiswa yang tersedia.

Kegiatan pelatihan ini perlu diujicobakan di sekolah-sekolah lainnya di kota Bandung untuk memberikan pengetahuan tentang bagaimana menyusun strategi dan merealisasikan perencanaan dan penetapan tujuan di masa yang akan datang terkait dengan pendidikan lanjut pada remaja.

Untuk meningkatkan manfaat pelatihan motivasi bagi peserta, maka sebaiknya kegiatan pelatihan dilakukan di awal kelas XII. Dengan demikian, setelah mengikuti kegiatan pelatihan remaja/siswa dapat menerapkan perencanaan studi masa depannya dengan segera dan dapat melakukan evaluasi.

Untuk mengetahui dampak dari pelatihan ini, maka sebaiknya pengukuran mengenai manfaat pelatihan dan evaluasi rencana studi siswa/remaja peserta pelatihan motivasi dilakukan secara berkala setelah pelatihan dilakukan.

\section{Ucapan terima kasih}

Puji syukur kami ucapkan kepada Tuhan Yang Maha Esa atas seluruh rahmat dan karunia-Nya. Terima kasih kami ucapkan kepada DIPA BLU UNPAD yang telah mendanai kegiatan penelitian ini. Terima kasih banyak juga untuk pimpinan 
fakultas Psikologi dan Pertanian yang telah memberikan dukungan semangat agar kegiatan pelatihan dan penelitian ini dapat berlangsung. Terimakasih untuk kerjasama dari pimpinan SMAN Jatinangor dan siswa SMAN Jatinangor yang telah berpartisipasi dalam kegiatan pelatihan motivasi berprestasi. Dan akhirnya terima kasih banyak untuk LPPM Unpad yang telah memberikan kesempatan kepada kami untuk melakukan penelitian ini dan membantu selama proses penyusunan proposal dan laporan akhir.

\section{DAFTAR PUSTAKA}

Christensen, Larry B. 2004. Experimental Methodology. Ninth edition. Pearson Education, Inc.

Kirkpatrick, D. L. \& James D. Kirkpatrick. 2006. Evaluating training programs: The four levels, 3rd ed. San Franciso: Berrett-Koehler Publishers

Nurmi, J. E. 1989. Adolescents' Orientation to The Future: Development of Interest and Plans, Related Attributions and Affects, in The Life-Span Context., Commentationes Scientiarium Socialium

Nurmi, J. E. 1996. Future Time and Self Direction Process: Conceptualization and Measurement. Finland: University of Jyvaskyla 